\title{
Ecology of a Two-barred Crossbill (Loxia leucoptera) irruption to Norway in 2019-20: altitudinal migration and interspecific habitat differences
}

\section{Svein Dale}

Faculty of Environmental Sciences and Natural Resource Management, Norwegian University of Life Sciences, P.O.Box 5003, NO-1432 Ås, Norway. Correspondence; e-mail: svein.dale@nmbu.no

\begin{abstract}
Two-barred Crossbills (Loxia leucoptera) have cyclic irruptions to Norway, but are generally uncommon and breeding is rare. Here I analyse data on a large irruption occurring in 2019-20 to assess the magnitude of the irruption and the ecological niche of the species. The irruption lasted one year, starting in July 2019 and ending in June 2020. Total numbers reported by birdwatchers to the website of the National Biodiversity Information Centre in Norway were ca. 7,000 individuals. Breeding indications were reported from nearly 100 sites. Analyses of elevation of records indicated that birds were often seen at low elevations before the breeding season in February-June, but moved to higher elevations during the breeding season. In a focal study area in SE Norway, breeding season surveys along elevational gradients indicated that Two-barred Crossbills occurred at higher elevations, and often close to summits of hills, perhaps representing preferences for more open forest habitats. Two-barred Crossbills often co-occurred with other seed-eating bird species, but presence was more closely related to numbers of Common Redpoll (Acanthis flammea), than to Eurasian Siskin (Spinus spinus) or cogeneric Common Crossbill (L. curvirostra). Similarly, the Common Redpoll also increased strongly in abundance with elevation, whereas the other two species did so to a lesser degree. These data suggest that the Two-barred Crossbill favors montane forests during the breeding season, and thereby has a different niche than the Common Crossbill which is distributed more widely across all elevations.
\end{abstract}

Keywords: altitudinal migration, elevational gradients, habitat selection, interspecific differences, niche

\section{INTRODUCTION}

Many bird species in boreal forests show large fluctuations in population size from one year to another due to cyclic variations in food abundance. For example, birds specializing on seeds from masting trees enjoy superabundant food in some years while other years provide little food (Newton 1972, 1998). During peak resource years, the number of individuals breeding, reproductive success and survival are high leading to a large population size (Newton 1972, 1998). Subsequent decline in food availability often causes emigration and irruption to areas outside the regular distribution range (Svärdson 1957, Bock \& Lepthien 1976, Koenig \& Knops 2001, Newton 2006).

Crossbills (Loxia spp.) are highly adapted to exploit seed crops of conifer trees. The Two-barred Crossbill is a specialist on seeds from cones of larches (Larix spp.), and has a more northern distribution than the Common Crossbill (L. curvirostra) which in northern parts of Europe specializes on seeds of Norway Spruce (Picea abies; Newton 1972, Cramp \& Perrins 1994). However, during irruptions Two-barred Crossbills can occur in areas without larches, and may then switch to seeds of spruces (Picea spp.) as an alternative food source. However, little is known about how Two- barred Crossbills and Common Crossbills segregate if they occur in sympatry, neither in areas where both are regular breeders, nor in areas where sympatry is temporary during a Two-barred Crossbill irruption. Newton (1972) even argued that the two species rarely occur together in the same place in the same year.

Two-barred Crossbills occur at fairly regular intervals in Scandinavia (Larsen \& Tombre 1989) due to irruptions originating from the normal distribution range further east (Cramp \& Perrins 1994). Recent large irruptions have taken place in at least 1995, 2002 and 2008 (Sørhuus et al. 1996, Nilsson 2009), and a large Two-barred Crossbill irruption reached Scandinavia in the summer of 2019. The latter irruption also reached further west and was one of the largest recorded in Britain (Cooper et al. 2019). Irruptions do not normally lead to widespread breeding in Norway although breeding has occurred more commonly after recent irruptions (Sørhuus et al. 1996, Bjerke 2015). Even in peak years less than 100 pairs are thought to breed in Norway (Shimmings \& Øien 2015).

Here, I summarize information on the magnitude of the 2019 irruption of Two-barred Crossbills to Norway, and how many pairs may have bred the following year before the irruption ended in the summer of 2020. In particular, I analyse data on elevation of records and 
Table 1. Data material used for analyses of Two-barred Crossbill (Loxia leucoptera) ecology. Data for the whole of Norway were from www.artsobservasjoner.no whereas data from Oslo and Akershus were collected during the present study. The $500 \mathrm{~m}$ a.s.l. limit refers to the maximum elevation of sites. ,Interspecific' refers to analyses of relationships between the Two-barred Crossbill and three other species of seed-eating birds (Common Crossbill Loxia curvirostra, Eurasian Siskin Spinus spinus, Common Redpoll Acanthis flammea).

\begin{tabular}{llll} 
Region and data set & Sample size & Details & Variables analyzc \\
\hline $\begin{array}{l}\text { Norway } \\
\text { Citizen data }\end{array}$ & $\begin{array}{ll}\text { 1,364 records } \\
2019-2020\end{array}$ & $\begin{array}{l}1,273 \text { records } \\
\text { from July 2019-June 2020 } \\
\text { (from 962 sites) }\end{array}$ & $\begin{array}{l}\text { Total numbers } \\
\text { Elevation }\end{array}$ \\
& 427 records from Feb-June 2020 & Interspecific \\
& & Breeding
\end{tabular}

Oslo and Akershus

All sites 191 sites

Elevation

Habitat

Interspecific

$\begin{array}{llll}\text { Sites }>500 \text { m a.s.1. } & 49 \text { sites } & \text { Subset of 'All sites' } & \begin{array}{l}\text { Elevation } \\ \text { Interspecific }\end{array} \\ \text { Elevational gradient } & 23 \text { surveys } & \text { Includes } 71 \text { sites } & \text { Density } \\ & & (48 \geq 500 \mathrm{~m} \text { a.s.l., } & \text { Elevation } \\ & & 23<500 \mathrm{~m} \text { a.s.1. }) & \end{array}$

co-occurrence with other seed-eaters, in particular the Common Crossbill, to characterize the ecological niche occupied by the Two-barred Crossbill during an irruption. Although food competition may be low in a year with abundant supplies of spruce seeds (cf. Benkman 1988), differences in the spatial distribution of the two crossbill species may reveal differences in habitat preferences and their ecological niches. Because previous sources considered the Two-barred Crossbill to be more northern and to occupy more open habitats (Newton 1972, Cramp \& Perrins 1994), I predicted that the Two-barred Crossbill would be found at higher elevation than the Common Crossbill, as also indicated by Sørhuus et al. (1996). I also predicted that the Twobarred Crossbill would occur more often together with the Common Redpoll (Acanthis flammea) which has a more montane distribution in Norway than with the Common Crossbill and another seed-eater, the Eurasian Siskin (Spinus spinus; Haftorn 1971, Gjershaug et al. 1994).

\section{METHODS}

\section{Study areas}

Data were collected at two spatial scales (Table 1). For the national scale, data from the whole of Norway was used. Records of Two-barred Crossbills from 2019-20 submitted to the website of the National Biodiversity
Information Centre (www.artsobservasjoner.no; this is an online portal where volunteers can report observations of species) were from all counties in Norway, from Agder in the south (ca. $58^{\circ}$ North) to Finnmark in the north (up to ca. $70^{\circ}$ North), and from Vestland in the west (ca. $5^{\circ}$ East) to Finnmark in the east (ca. $30^{\circ}$ East). Elevation of records varied from sea level to about $1,000 \mathrm{~m}$. In Norway, the upper limit of forest varies considerably (Odland et al. 1992), from ca. 900-1,100 m a.s.1. in Eastern Norway (the counties Innlandet, Viken, Oslo, Vestfold and Telemark, Agder), 500-1,000 m in Western Norway (the counties Rogaland, Vestland, Møre and Romsdal), 400-700 m in Middle Norway (Trøndelag county), and 0-400 $\mathrm{m}$ in Northern Norway (the counties Nordland, Troms and Finnmark).

For the local scale, I surveyed a large number of sites in the Oslo and Akershus regions (Akershus is part of Viken county) in southeastern Norway during 31 March-23 June 2020. The 191 sites included in this study (Table 1) had a significant proportion of forest, whereas sites with mostly wetland or farmland habitats were excluded because the study species were associated with forest habitat. Sites were generally defined according to topographical and spatial features (such as hills, valleys, forest patches surrounded by other habitats etc.), and had areas of ca. 50-500 ha. Sites were defined previously for other purposes (see e.g. Dale et al. 2001).

The surveyed sites were located along an elevational 
gradient from close to the sea level near the coast in the south to about $800 \mathrm{~m}$ a.s.l. in the northwestern parts of Akershus. Sites closest to the coast were within the nemoral zone, but most sites were located in the boreal zone dominated by coniferous trees [mainly spruce and Scots Pine (Pinus sylvestris)] interspersed with varying proportions of deciduous trees [in particular Downy Birch, to a lesser degree also Eurasian Aspen (Populus tremula), Grey Alder (Alnus incana) and Silver Birch (B. pendula)]. Most of the boreal forests in Oslo and Akershus are production forests so that there is a mosaic of mature forest, clear-cuts and regenerating forest. Old-growth forest occurs mainly on top of hills, and some areas of this forest type are protected as nature reserves.

\section{Citizen data}

From www.artsobservasjoner.no I retrieved all observations of Two-barred Crossbills during 2019-20. For each month I merged observations from the same sites (based on the site names used on the website and that sites should be at least $100 \mathrm{~m}$ apart), and I used the highest number of individuals observed within each month for each site. This is the basic unit used for analyses, and is termed a ,record' (observations from the same site in the same month). The data set contained 1,364 records from 2019-20, but most analyses are based on the specific months the irruption took place (July 2019-June 2020; see Figure 1), and there were 1,273 records during the irruption period. I also calculated a more conservative measure of number of Two-barred Crossbills by combining records from the same site across months, thereby using the number of unique sites $(\mathrm{n}=962)$ during the irruption period (July 2019-June 2020). Of these, 784 sites had one record (Two-barred Crossbills observed in only one month) whereas 178 sites had multiple records (mean $=$ 2.75 months with observations).

The elevation of the sites was recorded from digital maps of Norway (Kartverket, www.norgeskart.no). Elevation was recorded for the point indicating the location of the site on the map for each observation submitted to www.artsobservasjoner.no. The true location of the bird observations may sometimes differ from the map location because the maps often actually show the mid-point of a site with a certain extent. However, there is no reason to believe that the elevations of Two-barred Crossbill observations were biased relative to such mid-points, and in most cases elevation of the true locations would differ only slightly from the map locations compared to the total variation in elevation in the national data set.

Occurrence of other seed-eating bird species that are known to consume spruce seeds (Common Crossbill, Eurasian Siskin, Common Redpoll) was recorded as

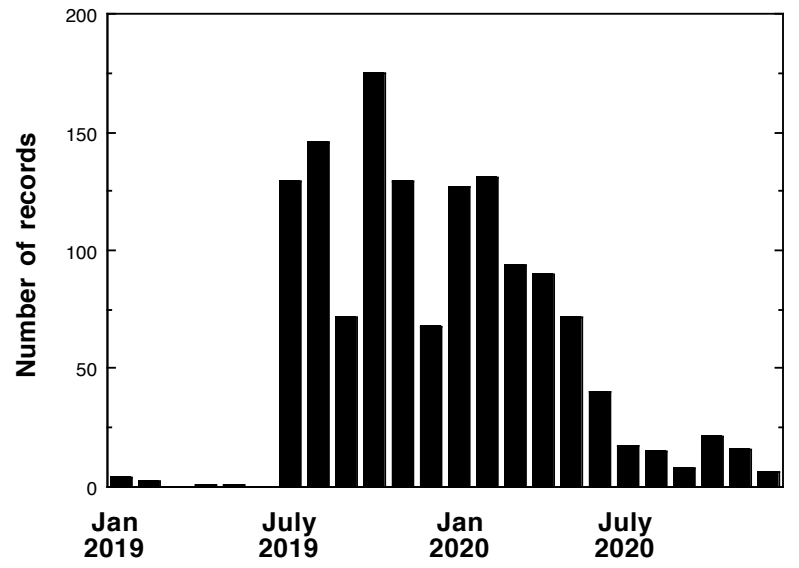

Figure 1. Number of records per month of Two-barred Crossbill (Loxia leucoptera) during the irruption to Norway in 2019-20 (total $\mathrm{n}=1,364)$.

present/absent based on which other species were reported from the same site and the same dates as the Two-barred Crossbill records. Presence/absence was recorded for all records where at least one of the three other seed-eaters were reported. If none of the other seed-eaters were reported, they were all recorded as absent if at least one other common passerine bird species had been reported. However, if only Twobarred Crossbill was reported, or only Two-barred Crossbill in combination with other rare bird species were reported, the three other seed-eaters were recorded with missing data because it was considered that the observer had not reported all bird species observed. For sites with reports from multiple dates within the same month, a species was recorded as present if it had been reported on at least one of the dates. Records of presence/absence of the other seed-eaters from one site in different months were treated as independent data. Data on co-occurrence with other seed-eaters were used to compare niche relationships during the potential breeding season of Two-barred Crossbills, and were therefore collected for the period FebruaryJune (Cramp \& Perrins 1994). Overall, there were 427 records of Two-barred Crossbill during the breeding season, and of these there were data on co-occurrence with other seed-eaters for 289 records from FebruaryJune 2020. Data on the other seed-eaters were missing for the remaining 138 records during the breeding season.

All observations of Two-barred Crossbills submitted to www.artsobservasjoner.no were also reviewed for information indicating breeding activity. Observations of nest building and immature birds during February-June 2020 were used as indications of breeding. Observations of pairs or singing males during February-June 2020 were taken as evidence of possible breeding. Information on breeding activity was based on the strongest indication of breeding (nesting $>$ pair and song $>$ song $>$ pair) for each site across all months 


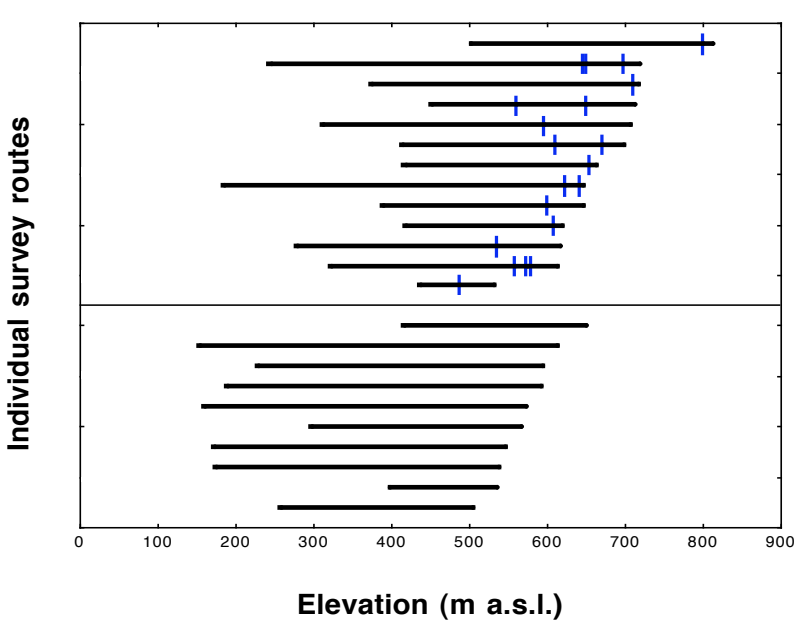

Figure 2. Elevation range of survey routes and elevation of records of Two-barred Crossbills (Loxia leucoptera) in Oslo and Akershus during the breeding season of 2020. Thick horizontal black lines indicate survey routes and blue vertical bars indicate Two-barred Crossbill records. The upper part of the figure shows survey routes with Two-barred Crossbill records ( $n=13$, total of 20 records of 28 individuals) whereas the lower part of the figure shows survey routes with no records $(n=10)$.

of the breeding season. Out of a total of 343 unique sites with observations of Two-barred Crossbills during the breeding season, 265 sites had additional information reported (observation of pairs or activity such as overflying individuals, foraging or breeding behaviours) which permitted assessment of breeding activity.

\section{Field surveys}

Field surveys in Oslo and Akershus took place from sunrise until midday on days with fair weather conditions. A total of 191 sites were surveyed (Table 1). Sites visited after 12:00 h were in general not included because of lower bird activity. However, if surveys started before 12:00 $\mathrm{h}$ they were included even if they ended after 12:00 $\mathrm{h}$, and in these cases the whole survey duration was used, including the parts taking place after 12:00 h. Surveys were conducted mainly on foot or with skis, and occasionally with bicycle. All birds recorded (both birds seen and heard) along the survey routes were included in the counts without distance limits. I recorded both Two-barred Crossbills and the other seed-eaters (Common Crossbill, Eurasian Siskin, Common Redpoll). A record in the field surveys was defined as one observation of one or more individuals of Two-barred Crossbills together.

On 23 field days, surveys spanned an elevational gradient where the highest point was set to be at least $500 \mathrm{~m}$ a.s.l. (Table 1). Total distance of all survey routes spanned $270.5 \mathrm{~km}$ and included 71 of the 191 sites surveyed (Table 1). Elevational gradient surveys started at a mean elevation of $313 \mathrm{~m}$ (range 154-503) and the maximum elevation reached was on average $626 \mathrm{~m}$ (range 505-812; see also Figure 2). Total survey duration on these 23 days was $121.8 \mathrm{~h}$. Survey time was strongly correlated with survey length $\left(r^{2}=0.83\right.$, $\mathrm{p}<0.0001$ ), and survey speed had an overall average of $2.22 \mathrm{~km} / \mathrm{h}$ (range $1.54-3.01 \mathrm{~km} / \mathrm{h}$ ). The numbers of Two-barred Crossbills encountered during the 23 survey routes were used to calculate observation rates as number of records or individuals per km surveyed. For analyses using a site as the sampling unit $(n=191)$, survey effort was recorded as the number of minutes spent surveying each site.

Elevation of sites in the field surveys was also recorded from www.norgeskart.no. For each site and survey route I recorded both lower and upper elevation surveyed, and I used those values to calculate mean elevation. The habitat of sites was classified as production forest (to a large degree affected by forestry, $\mathrm{n}=155$ ) or old-growth forest (containing at least some old-growth forest, $\mathrm{n}=36$ ). Of sites in the latter category, 25 were nature reserves.

\section{Statistical analyses}

Analyses of elevation of Two-barred Crossbill records at the national scale in relation to time periods [nonbreeding season (July-January) versus breeding season (February-June)] were conducted with t-tests, and were also broken down by region (Eastern, Western, Middle and Northern Norway). Comparisons of presence/ absence of the other three seed-eaters (Common Crossbill, Eurasian Siskin, Common Redpoll) were made with $\chi^{2}$-tests.

Analyses of elevation of records of all four species at the local scale (Oslo and Akershus) were conducted with logistic regression (presence/absence of Twobarred Crossbills) or linear regressions (numbers of all four species, log-transformed for Common Crossbill, Eurasian Siskin, Common Redpoll). Survey date and survey duration were included as covariates to control for temporal effects and survey effort, but were removed from models if they did not have significant effects $(p$ $<0.05$ ). Analyses of presence/absence of Two-barred Crossbills in relation to habitat were conducted with logistic regressions that also included survey duration and mean elevation of sites $(n=191)$.

Analyses of how presence/absence and numbers of Two-barred Crossbills were related to numbers of the other seedeaters were conducted with logistic and linear regressions. Log-transformed numbers of the other seed-eaters were explanatory variables. All statistical analyses were conducted with JMP Pro version 15. 
Table 2. Analyses of the relationships between mean elevation of sites and a) presence/absence and numbers of Twobarred Crossbills (Loxia leucoptera), and b) log-transformed number of other seed-eaters (Common Redpolls (Acanthis flammea), Eurasian Siskins (Spinus spinus), Common Crossbills (Loxia curvirostra) recorded in Oslo and Akershus during the breeding season of 2020. For all species, analyses were conducted for both all sites $(\mathrm{n}=191)$ and for sites surpassing $500 \mathrm{~m}$ a.s.1. $(\mathrm{n}=49)$. Presence/absence was analysed with logistic regression, number of individuals with linear regression. Survey date and survey duration were included in models when they were significant, but effects are not shown in the table.

\begin{tabular}{|c|c|c|c|c|}
\hline Species and data set & Slope & SE & $\begin{array}{l}\text { Test } \\
\text { statistic }\end{array}$ & $\mathbf{p}$ \\
\hline \multicolumn{5}{|l|}{ a) } \\
\hline Two-barred Crossbill presence/absence & & & $\chi^{2}$ & \\
\hline 191 sites & -0.014 & 0.004 & 12.41 & 0.0004 \\
\hline 49 sites & -0.014 & 0.006 & 5.44 & 0.020 \\
\hline Two-barred Crossbill numbers & & & $\mathrm{t}$ & \\
\hline 191 sites & 0.0009 & 0.0002 & 3.99 & $<0.0001$ \\
\hline 49 sites & 0.0039 & 0.0017 & 2.32 & 0.025 \\
\hline \multicolumn{5}{|l|}{ b) } \\
\hline Common Crossbill numbers & & & $\mathrm{t}$ & \\
\hline 191 sites & 0.0018 & 0.0002 & 9.50 & $<0.0001$ \\
\hline 49 sites & 0.0004 & 0.0007 & 0.50 & 0.62 \\
\hline Eurasian Siskin numbers & & & $\mathrm{t}$ & \\
\hline 191 sites & 0.0019 & 0.0002 & 12.47 & $<0.0001$ \\
\hline 49 sites & 0.0012 & 0.0007 & 1.76 & 0.09 \\
\hline Common Redpoll numbers & & & $\mathrm{t}$ & \\
\hline 191 sites & 0.0035 & 0.0002 & 16.27 & $<0.0001$ \\
\hline 49 sites & 0.0070 & 0.0010 & 7.26 & $<0.0001$ \\
\hline
\end{tabular}

\section{RESULTS}

\section{Timing of irruption and number of birds observed}

The irruption of Two-barred Crossbills in Norway started in July 2019 and most birds had disappeared by the end of June 2020 (Figure 1). At the national scale, there was an uncorrected grand total of 1,273 records of 7,115 individuals during the period July 2019-June 2020. A more conservative estimate (combining records from all months for each site and using the highest monthly count) indicated 962 unique sites with a total of 5,740 individuals. A large proportion of the records were from Eastern Norway (44\% of all records), in particular during the breeding season (February-June, $59 \%$ of breeding season records; regional distribution of records was significantly different in the non-breeding season compared to the breeding season: $\chi^{2}=63.60$, df $=3, \mathrm{p}<0.0001)$. Overall, $34 \%$ of the records were from the breeding season (427 records of 2,048 individuals), and 343 unique sites had 1,761 individuals during the breeding season.
During the 23 survey routes in Oslo and Akershus during the breeding season, there were a total of 20 records of 28 Two-barred Crossbill individuals. Total survey distance was $270.5 \mathrm{~km}$, and Two-barred Crossbill observation rate was 0.74 records $/ 10 \mathrm{~km}$ or 1.04 individuals $/ 10 \mathrm{~km}$. During survey routes, all records except one (488 m a.s.1.) were above $500 \mathrm{~m}$ elevation (Figure 2) where $155.2 \mathrm{~km}$ was surveyed. Observation rates for areas above $500 \mathrm{~m}$ a.s.1. were 1.22 records $/ 10 \mathrm{~km}$ and 1.68 individuals $/ 10 \mathrm{~km}$. The 20 records during the 23 survey routes were from 16 different sites. One additional record of one individual was made outside survey routes (346 m a.s.l.).

\section{Breeding behaviour}

Before the breeding season, there were observations of Two-barred Crossbills singing from 22 different sites (July: 5, August: 6, September: 1, October: 4: November: 1, January: 5).

During the breeding season, there were 107 records 
with breeding indications from 94 different sites, out of a total of 343 sites with Two-barred Crossbill observations and 265 sites with information on activity of birds observed. Breeding indications were from February (29 records), March (23 records), April (29 records), May (18 records) and June (8 records). Nesting activity or immature birds were recorded from 19 sites, mostly from Eastern Norway (Innlandet county: 9 sites, Viken county: 5 sites). Pairs or singing birds were recorded from 75 sites (pair and song: 8 sites; song: 27 sites; pair: 40 sites), mostly from Eastern Norway (Innlandet county: 41 sites, Viken county: 9 sites) and Troms (14 sites). In Eastern Norway, where the bulk of the breeding behaviours were observed, the mean elevation of sites with breeding indications was $764 \mathrm{~m}($ median $=839 \mathrm{~m}$, range $=136-1,015 \mathrm{~m}, \mathrm{n}=66$ sites).

\section{Elevation}

At the national scale, elevation of records was higher during the breeding season (February-June: mean 462 $\mathrm{m}, \mathrm{SE}=18, \mathrm{n}=427$ ) than before the breeding season (July-January: mean elevation $223 \mathrm{~m}, \mathrm{SE}=10, \mathrm{n}=846$; $\mathrm{t}=-12.78, \mathrm{p}<0.0001$; Figure $3 \mathrm{a})$. Temporal variation in elevation was mainly due to a higher elevation during the breeding season in Eastern Norway (July-January: mean elevation $469 \mathrm{~m}, \mathrm{SE}=18, \mathrm{n}=303$; FebruaryJune: mean $729 \mathrm{~m}, \mathrm{SE}=13, \mathrm{n}=252 ; \mathrm{t}=-11.20, \mathrm{p}<$ 0.0001 ; Figure $3 b$ ). This pattern was not present in the other three regions (Western Norway: July-January: mean elevation $111 \mathrm{~m}, \mathrm{SE}=11, \mathrm{n}=222$; FebruaryJune: mean $105 \mathrm{~m}, \mathrm{SE}=17, \mathrm{n}=69 ; \mathrm{t}=0.26, \mathrm{p}=0.79$; Middle Norway: July-January: mean elevation 120 $\mathrm{m}, \mathrm{SE}=20, \mathrm{n}=88$; February-June: mean $=67 \mathrm{~m}, \mathrm{SE}$ $=27, \mathrm{n}=36 ; \mathrm{t}=1.49, \mathrm{p}=0.14$; Northern Norway: July-January: mean elevation $48 \mathrm{~m}, \mathrm{SE}=4, \mathrm{n}=233$; February-June: mean $=53 \mathrm{~m}, \mathrm{SE}=5, \mathrm{n}=70 ; \mathrm{t}=-0.61$, $\mathrm{p}=0.54)$.

Surveys routes in Oslo and Akershus where Twobarred Crossbills were recorded had higher maximum elevation (mean $669 \mathrm{~m}, \mathrm{SE}=19, \mathrm{n}=13$ ) than survey routes with no records (mean $571 \mathrm{~m}, \mathrm{SE}=14, \mathrm{n}=10 ; \mathrm{t}$ $=3.92, \mathrm{p}=0.0008$; Figure 2 ). Records were on average $48 \mathrm{~m}$ below the summit of hills (range 4-152 m, $\mathrm{n}=20$; Figure 2). Only one out of the 20 records of Two-barred Crossbills was below the middle survey elevation (mean of minimum and maximum elevation of a survey route; Figure 2). Two-barred Crossbill observation locations were on average $83 \%$ of the distance on the way to the summit of survey routes (range $42-99 \%$, Wilcoxon signed ranks test based on deviance from random expected value of $50 \%$ of the way; $z=-3.85, p$ $<0.0001)$.

Two-barred Crossbills were recorded in 17 out of the 191 sites surveyed in Oslo and Akershus. Presence and

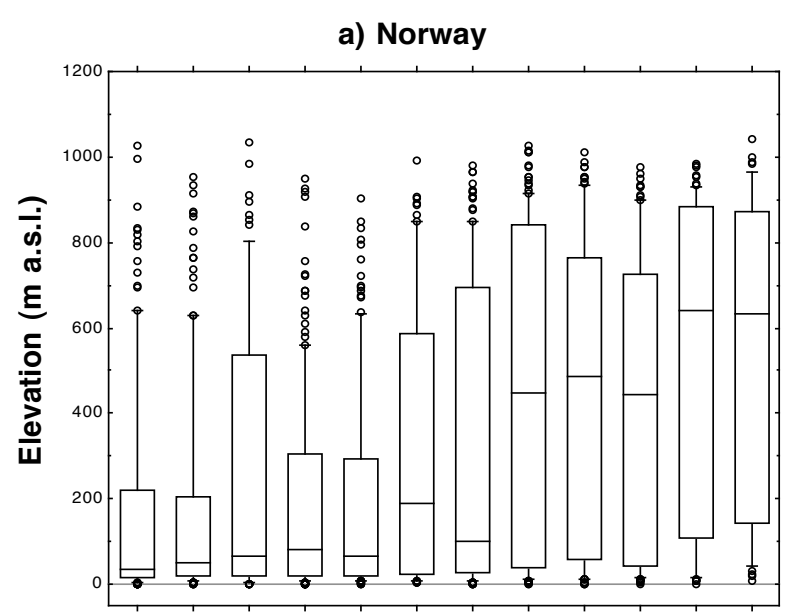

b) Eastern Norway

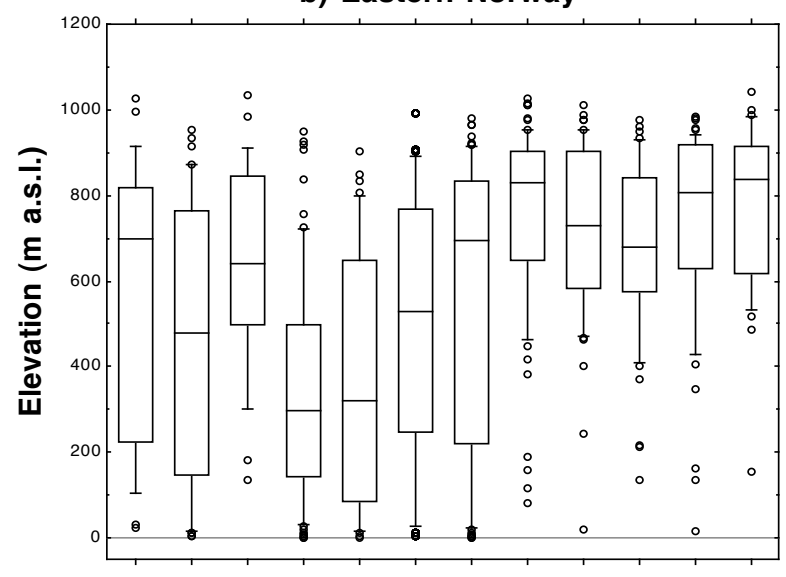

July Aug Sept Oct Nov Des Jan Feb Mar Apr May June

Figure 3. Boxplots of elevation of records of Two-barred Crossbills (Loxia leucoptera) in a) the whole of Norway (n $=1,237)$ and $b)$ Eastern Norway $(n=555)$ in relation to time of year (July 2019-June 2020). Boxes indicate 25th, 50th and 75th percentiles, whiskers indicate 10th and 90th percentiles.

numbers of Two-barred Crossbills recorded increased strongly with elevation (Table 2a, Figure 4a). Presence and numbers recorded also increased with elevation even when considering only sites that surpassed $500 \mathrm{~m}$ a.s.1. $(n=49$; Table 2a).

\section{Habitat}

In Oslo and Akershus, five records of 8 individuals were from within nature reserves. Thirteen records of 20 individuals were made in areas with old-growth forest, all of which had an open forest structure. The remaining 8 records of 9 individuals were from areas affected by forestry, but none of these observations were from dense forest. Sites with old-growth forest were used more often (Two-barred Crossbills present in 9 of 36 sites) than sites with forestry (present in 8 out of 155 sites; $\chi 2=11.84, \mathrm{df}=1, \mathrm{p}=0.0006)$. However, 
a) Two-barred Crossbill

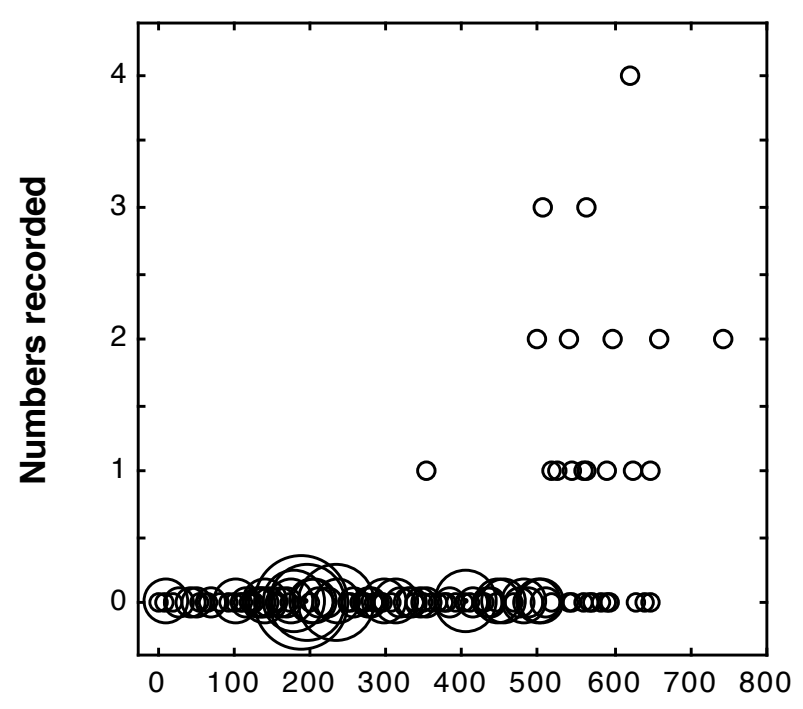

Mean elevation of sites $(\mathrm{m})$

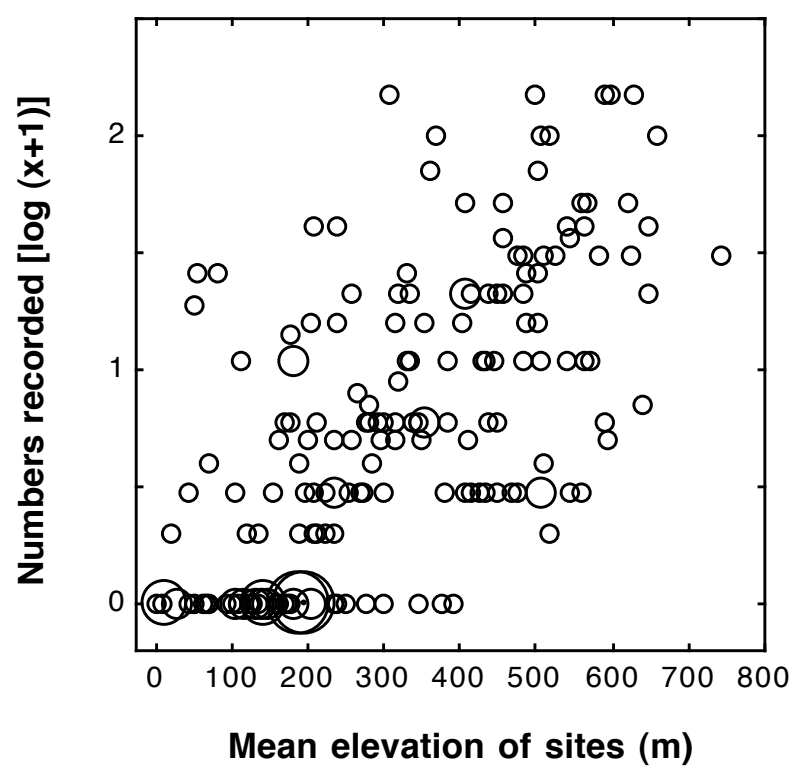

c) Eurasian Siskin

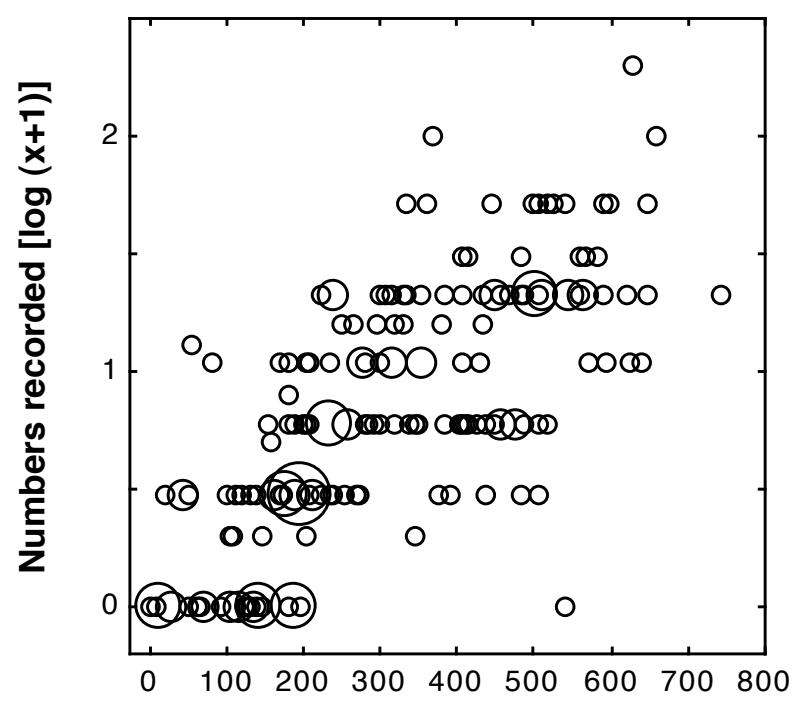

Mean elevation of sites $(\mathrm{m})$

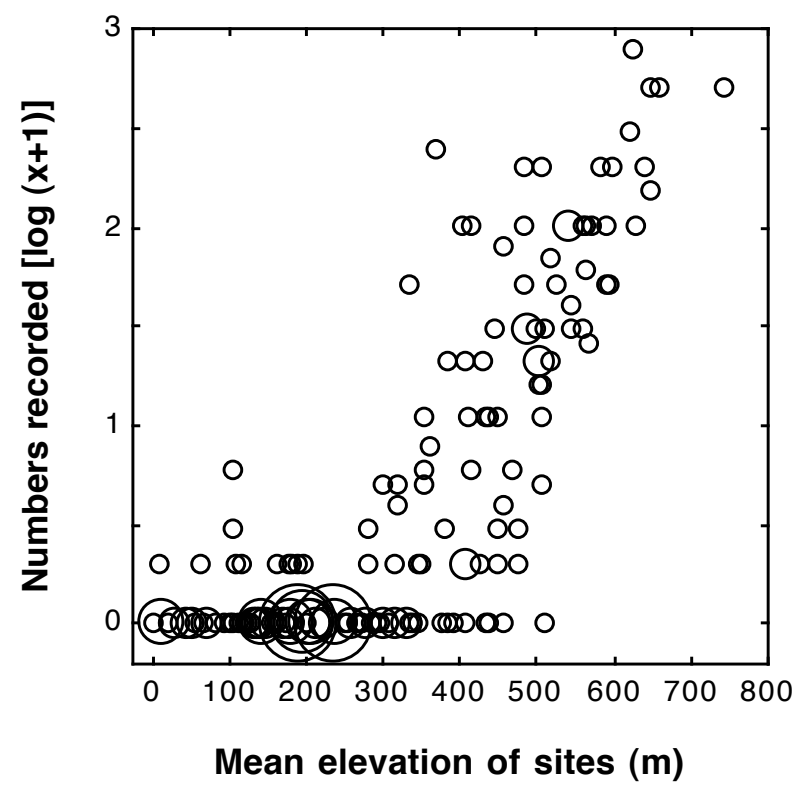

Figure 4. Relationships between mean elevation of sites and a) numbers of Two-barred Crossbills (Loxia leucoptera), and logtransformed numbers of b) Common Crossbills (Loxia curvirostra), c) Eurasian Siskins (Spinus spinus), and d) Common Redpolls (Acanthis flammea) recorded in Oslo and Akershus during the breeding season of 2020. Data from 191 sites are shown. Overlapping data points are shown with larger symbols.

a model controlling for survey duration and elevation indicated no significant preference for old-growth habitat (logistic regressions; all sites $(n=191)$ : survey duration $\mathrm{p}=0.005$, mean elevation $\mathrm{p}<0.0001$, habitat $\mathrm{p}=0.55$; sites surpassing $500 \mathrm{~m}$ elevation $(\mathrm{n}=49)$ : survey duration $\mathrm{p}=0.005$, mean elevation $\mathrm{p}=0.008$, habitat $p=0.59$ ), suggesting that preference for higher elevation was the main driver for occurring in areas with old-growth forest.

\section{Comparisons with other seed-eaters}

At the national scale, there were 289 records of Twobarred Crossbills during February-June 2020 where information on other seed-eaters was available. 
Table 3. Analyses of how a) presence/absence and b) number of Two-barred Crossbills (Loxia leucoptera) were related to log-transformed numbers of Common Crossbills (Loxia curvirostra), Eurasian Siskins (Spinus spinus), and Common Redpolls (Acanthis flammea) recorded in Oslo and Akershus during the breeding season of 2020. Analyses were based both on all sites $(\mathrm{n}=191$, and sites that surpassed $500 \mathrm{~m}$ a.s.l. $(\mathrm{n}=49)$. Presence/absence was analysed with logistic regression, number of individuals with linear regression.

\begin{tabular}{|c|c|c|c|c|}
\hline Variable & Slope & SE & $\begin{array}{l}\text { Test } \\
\text { statistic }\end{array}$ & $\mathbf{p}$ \\
\hline \multicolumn{5}{|c|}{ a) Presence/absence of Two-barred Crossbill } \\
\hline 191 sites & & & $\chi^{2}$ & \\
\hline Common Crossbill & -1.243 & 0.975 & 1.62 & 0.20 \\
\hline Eurasian Siskin & -0.801 & 1.145 & 0.49 & 0.48 \\
\hline Common Redpoll & -1.867 & 0.567 & 10.83 & 0.001 \\
\hline 49 sites & & & $\chi^{2}$ & \\
\hline Common Crossbill & -1.214 & 1.123 & 1.17 & 0.28 \\
\hline Eurasian Siskin & -1.461 & 1.511 & 0.93 & 0.33 \\
\hline Common Redpoll & -1.802 & 0.760 & 5.62 & 0.018 \\
\hline \multicolumn{5}{|c|}{ b) Numbers of Two-barred Crossbills recorded } \\
\hline 191 sites & & & $\mathrm{t}$ & \\
\hline Common Crossbill & 0.113 & 0.090 & 1.26 & 0.21 \\
\hline Eurasian Siskin & -0.008 & 0.104 & -0.08 & 0.94 \\
\hline Common Redpoll & 0.311 & 0.055 & 5.63 & $<0.001$ \\
\hline 49 sites & & & $\mathrm{t}$ & \\
\hline Common Crossbill & 0.406 & 0.312 & 1.30 & 0.20 \\
\hline Eurasian Siskin & 0.318 & 0.386 & 0.82 & 0.42 \\
\hline Common Redpoll & 0.523 & 0.179 & 2.92 & 0.006 \\
\hline
\end{tabular}

Overall, Common Crossbills were present in $57 \%$ of cases, Eurasian Siskin in $35 \%$ of cases, and Common Redpolls in $55 \%$ of cases $\left(\chi^{2}=36.88\right.$, df $=$ $2, \mathrm{p}<0.0001)$. Similar patterns were found for Eastern Norway $(n=184)$ : Common Crossbills were present in $66 \%$ of cases, Eurasian Siskin in $41 \%$ of cases, and Common Redpolls in $66 \%$ of cases $\left(\chi^{2}=32.09\right.$, $\mathrm{df}=2, \mathrm{p}<0.0001)$. Elevation of sites where Common Crossbills were present was on average $93 \mathrm{~m}$ higher than sites where they were absent (present: mean $=517$ $\mathrm{m}, \mathrm{SE}=26, \mathrm{n}=166$; absent: mean $=424 \mathrm{~m}, \mathrm{SE}=36, \mathrm{n}$ $=123 ; \mathrm{t}=2.18, \mathrm{p}=0.030)$, and for Eurasian Siskins the difference was on average $92 \mathrm{~m}$ (present: mean $=538$ $\mathrm{m}, \mathrm{SE}=32, \mathrm{n}=100$; absent: mean $=446 \mathrm{~m}, \mathrm{SE}=28, \mathrm{n}$ $=189 ; \mathrm{t}=2.08, \mathrm{p}=0.039$ ). For Common Redpolls the difference was on average $218 \mathrm{~m}$ (present: mean $=575$ $\mathrm{m}, \mathrm{SE}=27, \mathrm{n}=160$; absent: mean $=357 \mathrm{~m}, \mathrm{SE}=31, \mathrm{n}$ $=129 ; \mathrm{t}=5.31, \mathrm{p}<0.0001)$.

In Oslo and Akershus, all the three other seed-eater species were present at all the 17 sites where Two-barred Crossbills were recorded. All species became more common with increasing elevation when considering all sites ( $\mathrm{n}=191$, Table 2, Figure 4), but only the Twobarred Crossbill and the Common Redpoll showed significant relationships with elevation among sites surpassing $500 \mathrm{~m}$ elevation ( $\mathrm{n}=49$; Table 2, Figure 4).

In analyses of all sites in Oslo and Akershus ( $\mathrm{n}$ = 191), Two-barred Crossbills occurred more often at sites where the Common Redpoll was common (Table 3, Figure 5), whereas presence or numbers of Two-barred Crossbills were not independently related to numbers of Eurasian Siskins and Common Crossbills (Table 3 ). This was also the case when only considering sites that surpassed $500 \mathrm{~m}$ elevation $(\mathrm{n}=$ 49; Table 3). These differences were in particular due to low numbers of Common Redpolls at sites where Two-barred Crossbill were absent, whereas such sites had much larger numbers of Common Crossbills and Eurasian Siskins (Figure 5).

In Oslo and Akershus, Two-barred Crossbills were observed together with Common Crossbills in only one out of 21 records (one individual within a large flock of Common Crossbills). However, Common Crossbills were observed within $200 \mathrm{~m}$ from all Two-barred 


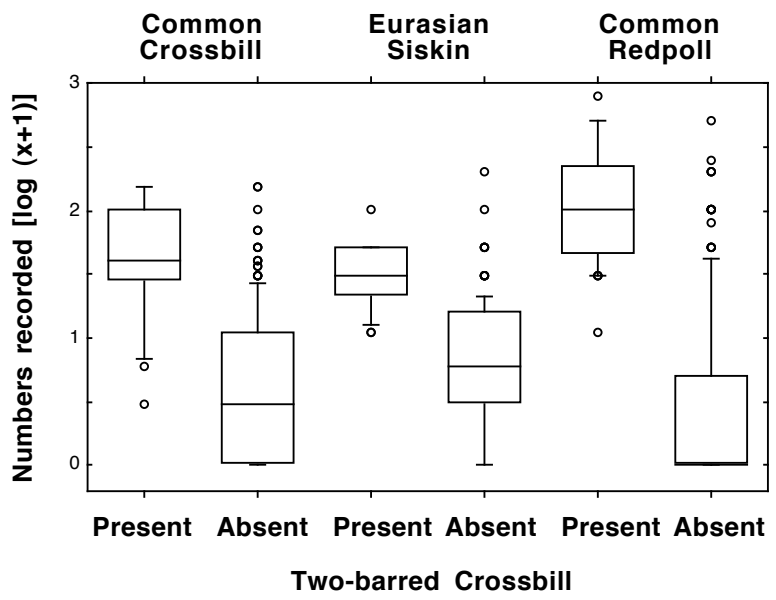

Figure 5. Boxplots of log-transformed numbers of Common Crossbills (Loxia curvirostra), Eurasian Siskins (Spinus spinus), and Common Redpolls (Acanthis flammea) recorded in Oslo and Akershus during the breeding season of 2020 for sites with records of Two-barred Crossbills (Loxia leucoptera; $\mathrm{n}=17$ ) and sites without records of Two-barred Crossbills $(\mathrm{n}=174)$. Boxes indicate 25th, 50th and 75th percentiles, whiskers indicate 10th and 90th percentiles.

Crossbills recorded. Furthermore, Common Crossbills were observed up to the summit in all survey routes where Two-barred Crossbills were recorded $(\mathrm{n}=13)$.

\section{DISCUSSION}

\section{Magnitude of irruption}

The 2019-20 irruption of Two-barred Crossbills to Norway started abruptly in July 2019 and most birds had disappeared by the end of June 2020. Total numbers reported by birdwatchers to the website www.artsobservasjoner.no were around 6,0007,000 individuals. However, this is probably a large underestimation, in particular because relatively few birdwatchers visit the vast boreal forests of Eastern Norway (ca. 56,000 $\mathrm{km}^{2}$, Larsson 2013). The bulk of the birds were observed in Eastern Norway, in particular during the breeding season. Compared to previous irruptions, the 2019-20 irruption was the largest known (see Appendix 1) although the magnitude of many previous irruptions are not well documented. The 2019-20 irruption was one of the largest recorded in Britain (Cooper et al. 2019). Breeding indications were reported from nearly 100 different sites in Norway, but this is probably also strongly underestimated. The number of Two-barred Crossbill pairs breeding in Norway has previously been suggested to be below 100 pairs even in good years (Shimmings \& Øien 2015). Thus, the 2019-20 irruption was probably the largest recorded, both in terms of total number of birds and number of pairs breeding.
The surveys in Oslo and Akershus indicated that approximately one individual was observed per 10 $\mathrm{km}$ survey length. Observation rates were higher in areas above $500 \mathrm{~m}$ elevation (1.68 individuals $/ 10$ $\mathrm{km})$. Converting observation rate to a density estimate depends on detectability, and the Two-barred Crossbill is not always easy to detect. Based on the field work conducted in Oslo and Akershus, I suggest that most individuals within $100 \mathrm{~m}$ on either side of the survey route may have been detected, but few further away. Densities may then have been 0.84 individuals $/ \mathrm{km}^{2}$. If some Two-barred Crossbills went undetected even within $100 \mathrm{~m}$ on either side of the survey route, the density would be higher. Assuming Two-barred Crossbills densities were similar in other forest areas within the elevation range $600-900 \mathrm{~m}$ in at least Innlandet and Viken counties (ca. 18,000 $\mathrm{km}^{2}$ forest area in this elevation zone), there would have been approximately 15,000 individuals only in that elevation zone in these two counties. Several thousand additional individuals may have occurred in other elevation zones in those two counties and in other parts of Norway.

\section{Elevation and habitat}

During the first part of the irruption (July-January) a large proportion of the observations of Two-barred Crossbills in Norway were at low elevations, often at coastal sites (in particular for Western, Middle and Northern Norway). However, during the breeding season (February-June) a larger proportion of the records were at higher elevations, and a higher proportion of the records were also from Eastern Norway. In Eastern Norway, breeding season records were often from montane forest and had a mean elevation of $729 \mathrm{~m}$. The data from the study areas in Oslo and Akershus supported that Two-barred Crossbills were mainly found at higher elevations, and many observations were close to the summit of hills in the range 500-700 $\mathrm{m}$ a.s.1.

In Oslo and Akershus, all observations of Twobarred Crossbills were in spruce-dominated forest, often with an open structure. The habitat of birds reported to www.artsobservasjoner.no across Norway could not be studied in detail, but many of the breeding season records from Eastern Norway were from montane forest in areas that are generally dominated by spruce forest or mixed spruce and birch forest. For many sites forest was mixed with moorland, and for records at the highest elevations even mountain heath (as indicated by plots on maps on www.artsobservasjoner.no). Thus, although habitat selection could not be quantified, it appears that montane spruce forest with an open structure is a preferred breeding habitat.

Altitudinal migration is common in many bird species, and many species breed at higher elevations than 
where they spend the non-breeding season (Barçante et al. 2017). The Two-barred Crossbill conformed to this pattern. However, because crossbills often start breeding in winter, even in February in the boreal zone (Cramp \& Perrins 1994), the upward migration to the breeding areas took place during the coldest part of the year. This makes the Two-barred Crossbill unusual among species classified as altitudinal migrants so far. However, during peak spruce seed years access to food does not differ much in relation to elevation, and breeding birds may have access to superabundant food also during mid-winter in montane areas.

\section{Comparisons with other seed-eaters}

The national data indicated that Two-barred Crossbills occurred together with Common Crossbills and Common Redpolls more often than Eurasian Siskins. Note, however, that the national data set only used data from sites where Two-barred Crossbills had been recorded. The data from the local study area in Oslo and Akershus indicated that all the three other seed-eaters occurred at sites where the Two-barred Crossbill was recorded. However, the data from Oslo and Akershus also permitted analyses of sites both with and without records of Two-barred Crossbills. These analyses showed more clearly that Two-barred Crossbill presence or numbers were most strongly associated with numbers of Common Redpolls. This association was in particular due to both species being mostly absent from sites at lower elevation, whereas both Common Crossbill and Eurasian Siskin occurred commonly at lower elevation sites in addition to being abundant at higher elevation sites. Thus, both the Twobarred Crossbill and the Common Redpoll have more distinctly montane distributions than the Common Crossbill and the Eurasian Siskin.

The niche differences between the two crossbill species therefore do not lead to allopatric distribution in Norway during an irruption of the Two-barred Crossbill. Rather, they are sympatric at the upper elevations of the distribution of the Common Crossbill. Sympatric distribution may be expected to lead to resource competition, but during years with masting by spruces, seed crops are likely so large that resources are not depleted even in areas where both species occur at the same time. Thus, the preference for higher elevation by the Two-barred Crossbill is probably not due to reduced competition with the Common Crossbill, but must have other explanations. Furthermore, breeding at higher elevation entails energy costs due to lower ambient temperatures, so climatic conditions do not provide an explanation either. One possible explanation may be that predation risk may be lower at higher elevations (Boyle 2008, Barçante et al. 2017). One potential predator that may be evaded by breeding at higher elevations is the Pygmy Owl (Glaucidium passerinum) which breeds more commonly at lower elevations (Solheim 1994). The Two-barred Crossbill is smaller than the Common Crossbill, and may therefore be more vulnerable to predation by the Pygmy Owl and have a larger benefit of breeding at higher elevations. This hypothetical exlanation for the distribution of Two-barred Crossbills remains to be tested with more detailed behavioural data.

Acknowledgements. I thank Geir A. Sonerud and two anonymous referees for comments on the manuscript.

\section{REFERENCES}

Barçante, L., Vale, M.M. \& Alves, M.A.S. 2017. Altitudinal migration by birds: a review of the literature and a comprehensive list of species. Journal of Field Ornithology 88: 321-335.

Benkman, C.W. 1988. Why white-winged crossbills do not defend feeding territories. Auk 105: 370-371.

Bjerke, B.A. 2015. Hekkefunn av båndkorsnebb på Golsfjellet i Oppland. Vår Fuglefauna 38: 76-78. (In Norwegian)

Bock, C.E. og Lepthien, L.W. 1976. Synchronous eruptions of boreal seed-eating birds. American Naturalist 110: 559-571.

Boyle, W.A. 2008. Can variation in risk of nest predation explain altitudinal migration in tropical birds? Oecologia 155: 397-403.

Cooper, D., Thomason, B. \& Fray, R. 2019. The recordbreaking Two-barred Crossbill irruption in Shetland, July-August 2019. https://www.birdguides.com/articles/ rare-birds/the-record-breaking-two-barred-crossbillirruption-in-shetland-july-au/

Cramp, S. \& Perrins, C.M. 1994. The Birds of the Western Palearctic. Volume VIII. Crows to Finches. Oxford University Press, Oxford.

Dale, S., Andersen, G.S., Eie, K., Bergan, M. \& Stensland, P. 2001. Guide til fuglelivet i Oslo og Akershus. Norsk Ornitologisk Forening, Oslo og Akershus. (In Norwegian)

Gjershaug, J.O., Thingstad, P.G., Eldøy, S. \& Byrkjeland, S. (eds.) 1994. Norsk fugleatlas. Norsk Ornitologisk Forening, Klæbu. (In Norwegian)

Haftorn, S. 1971. Norges Fugler. Universitetsforlaget, Oslo. (In Norwegian)

Koenig, W.D. \& Knops, J.M.H. 2001. Seed-crop size and eruptions of North American boreal seed-eating birds. Journal of Animal Ecology 70: 609-620.

Larsen, T. 1994. Båndkorsnebb Loxia leucoptera. Pp. 478-479 in: Gjershaug, J.O., Thingstad, P.G., Eldøy, S. \& Byrkjeland, S. (eds.). Norsk fugleatlas. Norsk Ornitologisk Forening, Klæbu. (In Norwegian)

Larsen, T. \& Tombre, I. 1989. Cyclic irruptions of two-barred crossbills in Scandinavia. Fauna norvegica Series C, Cinclus 12: 3-10.

Larsson, J.Y. 2013. Hvilket fylke har mest skog? http:// 
forskning.no/skog-skogbruk/2013/01/hvilket-fylke-harmest-skog. Retrieved on 21 January 2021.

Newton, I. 1972. Finches. Collins, London.

Newton, I. 1998. Population Limitation in Birds. Academic Press, San Diego.

Newton, I. 2006. Advances in the study of irruptive migration. Ardea 94: 433-460.

Nilsson, K. 2009. Invasion av bändelkorsnebb - hösten 2008. Fåglar i Uppland 36: 18-21.

Odland, A., Bevanger, K., Fremstad, E., Hanssen, O., Reitan, O. \& Aagaard, K. 1992. Fjellskog i Sør-Norge: biologi og forvaltning. NINA Oppdragsmelding 123: 1-90. (In Norwegian with English summary)
Shimmings, P. \& Øien, I.J. 2015. Bestandsestimater for norske hekkefugler. Norsk Ornitologisk Forening, rapport 2-2015. (In Norwegian)

Solheim, R. 1994. Spurveugle Glaucidium passerinum. Pp. 276-277 in: Gjershaug, J.O., Thingstad, P.G., Eldøy, S. \& Byrkjeland, S. (eds.) 1994. Norsk fugleatlas. Norsk Ornitologisk Forening, Klæbu. (In Norwegian)

Svärdson, G. 1957. The „invasion” type of bird migration. British Birds 50: 314-343.

Sørhuus, H., Vang, M. \& Østerås, T.R. 1996. Invasion of two-barred crossbills Loxia leucoptera in inner parts of Trøndelag 1995/96. Vår Fuglefauna 19: 131-133. (In Norwegian with English summary) 
Appendix 1. Number of Two-barred Crossbill individuals recorded in Norway during 1956-2019.

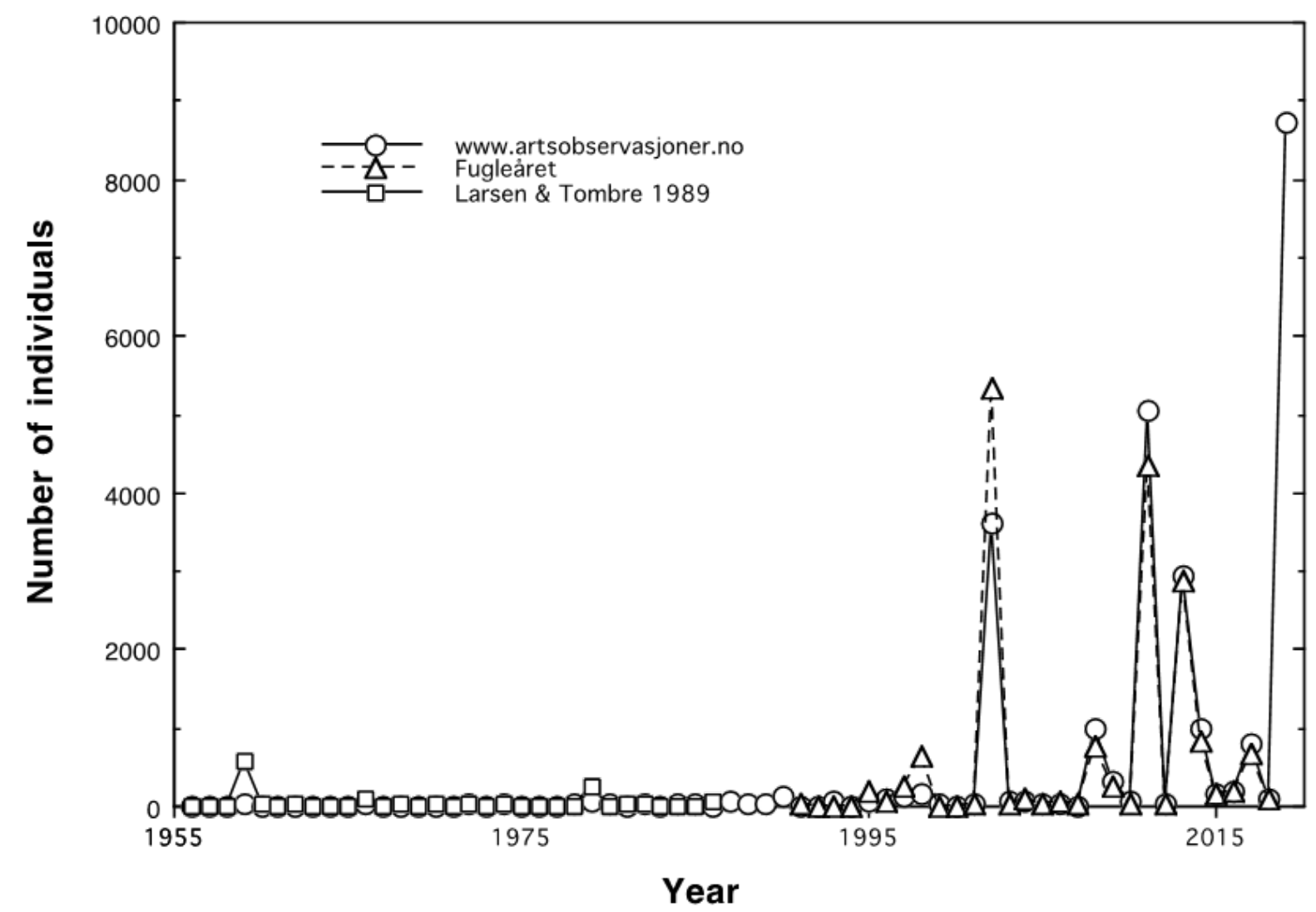

The figure shows the number of individuals of Twobarred Crossbills (Loxia leucoptera) recorded in Norway during 1956-2019 based on information from www.artsobservasjoner.no (for the period 1956 -2019), Fugleåret (for the period 1991-2018; a publication by the Norwegian Ornithological Society: https://www.naturogfritid.no/Boker/Tidsskrifter/ Fuglearet), and Larsen and Tombre (1989; Figure 1) (for the period 1956-1986).

Note that data for each year (year $\mathrm{x}$ ) include the second half (July-December) of year $\mathrm{x}$ and the first half (January-June) of year $\mathrm{x}+1$ (i.e. $2019=$ July 2019 - June 2020). For data from www.artsobservasjoner.no the number of individuals is the total sum of individuals from every report, and not checked for multiple records of the same birds [for example: for the 2019-2020 irruption the number used here is 8,713 individuals, whereas in the main text of this study the numbers used are 7,115 (sum of monthly maximum numbers across sites) and 5,740 (sum of one maximum number for the whole year across sites)].

Fugleåret presents total number of individuals corrected for multiple records of the same birds, but without clear specifications of how corrections were made. 